\title{
The Process of Urbanisation and Reconfiguration of Spanish and Portuguese Cities
}

\author{
Lorenzo López Trigal ${ }^{*}$
}

Department of Geography and Geology. Campus Universidad, 24071 León. Spain

\begin{abstract}
This study opens with concepts and features of new urban developments, current processes and the changing model of the city. It goes on to present the restructuring of territorial and urban systems in the Iberian Peninsula, with the consequent readjustment to city hierarchies and urban strategies. The text then focuses on a review of the characteristics of recent urban expansion based on, in the first place, the bibliography consulted, and in the second place, on field studies and interviews carried out with those responsible for various metropolises, which leads on to a comparative presentation of the pace and state of present day dynamics in Iberian cities.
\end{abstract}

Keywords: Urban dynamics, urban reconfiguration, urbanisation process, urban system, Iberian cities.

\section{INTRODUCTION AND MATERIALS}

The expansion of Spanish and Portuguese city limits in recent decades has become a steady phenomenon to the extent that the production of urban and industrial land, and the construction of new housing, facilities and infrastructures are included in urban expansion land use and zoning plans, which departs from the previous model of the compact city, and is founded on new periurban developments generally promoted by municipalities bordering the central urban and metropolitan city, above all in coastal areas. The result is an urbanisation process which is taking place at an unparalleled rate, over and above the rate of urban population growth, with an annual duplication of the number of building licenses for new housing in Spain (from three hundred thousand to four hundred thousand in the period $1960-$ 1990, and eight hundred thousand in 2005). This rate is even higher in medium-sized and big cities such as Vitoria (230,000 inhabitants), which, between 1990 and 2005, has gone from one thousand to three thousand new houses being built annually, and an expansion of more than $50 \%$ in surface area for residential purposes. At the same time, industrial land has increased by $35 \%$ and facilities and green zones by $100 \%$.

Urban and metropolitan reconfiguration is generalised here by different forms of urban sprawl (suburbanisation and periurbanisation, processes which have become the periurbanisation of coastal areas, and periurbanisation of agricultural areas in the interior) which has been creating the model of a diffuse or sprawling city through development along access routes to the city, industrial estates and scattered housing estates and the growth of previously rural centres in periurban areas. This advance of urbanisation leaves in its wake all kinds of vacuums and interstices in the suburban/exurban space of urban agglomerations, and the adoption of new forms of agglomeration depending on urban

*Address correspondence to this author at the Department of Geography and Geology. Campus Universidad, 24071 León. Spain; Tel: 987291048; Fax: 987291043; E-mail: 1.trigal@unileon.es size (urban area in the case of medium cities with more than 50,000 inhabitants, and metropolitan area in the case of big cities with more than 500,000 inhabitants, including the surrounding and neighbouring areas of new growth), and different models and trends (a more or less compact city, or more or less sprawling, being monocentric or polycentric).

This urbanisation process and consequent reconfiguration is causing new urban problems as well as certain challenges and opportunities related to the new territorial model of cities, new structures and organisation, different rural-urban relationships, added economic costs from the consumption of space, and the increase in socio-spatial segregation and fragmentation of the city. All these changes are happening at a rapid pace, and affect some smaller cities as well as virtually all medium and large Iberian cities, where considerable urban projects are underway and gathering force everywhere as a result of events and policies, of the implementation of a new interurban railway network, of large scale investments in new communications, facilities and peripheral urbanisation networks, and not forgetting the reformation and rehabilitation of central areas, and, in some cities, the regeneration of peripheral neighbourhoods and run down areas. To a certain extent, many of the large scale urban projects which were not carried out in the second half of the previous century have come into being in recent years, with the problem that this has given a free hand to private land owners, giving rise to the conclusion that given the results so far, these processes are not so much aimed at achieving the dream city of a few decades ago, as at a city with a strong spatial dynamic, marked by a tendency for unsustainable development which, if it is not controlled, will lead to the consolidation of a model with negative effects. If "Spain has become a heavily urbanised country...the question arises, Can the Spanish city maintain its traditional compactness, or will it lose its originality through emphasizing its dispersion, like other Western cities?" $[1, \mathrm{p}$. 34]. A question which can also be applied to Portuguese cities. 


\section{RESTRUCTURING OF THE TERRITORIAL AND URBAN PLANNING SYSTEMS}

It is appropriate at this point to analyse firstly the territorial and urban planning systems, affected by changes related to the urbanisation process.

The European southwest includes the Portuguese and Spanish national urban systems, which are connected with the French and Moroccan systems, and with the enclaves of Andorra and Gibraltar. In this context, the entry of Spain and Portugal into the European Union has favoured the integration of both their economies and their urban systems, and has promoted a process of 'restructuring Iberian building land' over the last twenty years. This has brought about new spatial relationships through increasing commercial exchange, greater integration of work and financial markets (as can be seen in the mobility of workers, and the investments made by firms on both sides), and in general in an increase of movement between Spanish and Portuguese cities. Nevertheless, there are some gaps in this new cooperation, notably between the Atlantic islands (not only between the neighbouring islands of the Azores and the Canary Islands, but also between the Portuguese islands of the Azores and Madeira), whilst at the same time the capital city of Madrid is becoming increasingly recognised as the hub or main platform for services to all this region.

On the other hand, the urban system is improving its communications at the same time as readjusting its urban hierarchy, so that the city network is in the middle of a process of change towards substantial improvements in interregional and interurban accessibility, and towards a greater fluidity in relationships. In this context, a regional reformulation of the territorial and urban planning system is required, which in 2006 had 54 million inhabitants and was divided into 10 territorial quadrants, five of which belonged in their entirety to the Spanish territorial system, two to the Portuguese system, whilst the other three were of a binational character, either Spanish-French or SpanishPortuguese, further divided into regional and sub-regional territories, with nodes in the following metropolises and medium-sized cities:

Galicia (2,700,000 inhabitants) with two metropolitan areas, Vigo and La Coruña, joined by an axis which pivots on Santiago de Compostela, and with the two interior cities of Orense and Lugo.

- $\quad$ North and Centre of Portugal (4,500,000 inhabitants), with the conurbation formed by the area of Greater Porto and the neighbouring cities of Braga, Guimarâes, Viana do Castelo, Aveiro, and further away, the double centre of Coimbra-Figueira.

- Lisboa and the south of Portugal (5,200,000 inhabitants) where the national capital stands out, closely related with the city of Setúbal within the metropolitan area, and cities further away such as Leiria, Évora or Faro.

- The North Atlantic Coast (4,000,000 inhabitants) a space which is difficult to articulate, formed by regions which are highly compartmentalised by the environment and by their own organisation (Asturias and Cantabria on the one hand, and the Basque
Country and the French Basque department on the other), spaces showing a marked polycentralism in urban areas (Vitoria, Santander-Torrelavega, San Sebastián-Bayonne) and metropolitan areas (central Asturias and Bilbao).

- Ebro valley (2,200,000 inhabitants) a space which functions as a linchpin between the interior and the coast, an area which includes the regions of Aragón, Navarra and La Rioja, where Zaragoza is of prime importance, and where the dynamic, medium sized cities of Pamplona and Logroño are to be found.

- $\quad$ The Mediterranean northeast (8,500,000 inhabitants) formed by Catalonia and the Balearic Isles, as well as the French department of the Eastern Pyrenees and Andorra. The second biggest capital city of the system, Barcelona, is located in this quadrant, and its metropolitan region contains half of the entire population, with the metropolis of Palma de Mallorca, and the cities of Perpignan, Gerona, Lérida and Tarragona-Reus as dependent nodes.

- Madrid and the Meseta (11,500,000 inhabitants) clearly the area of central importance and covering the greatest area. Madrid is the principal node, and its surroundings are characterised by a polycentric subsystem of cities; Castille and León, with the cities of Valladolid, Burgos, León and Salamanca; Castille and La Mancha, with the cities of Albacete, Toledo, and Talavera de la Reina; and Extremadura, with the cities of Cáceres and Badajoz.

- Levante $(6,100,000$ inhabitants $)$ where the autonomous regions of Valencia and Murcia have a high density of urban development, above all the metropolis of Valencia, the third biggest metropolis in Spain, as well as the urban and metropolitan areas of Alicante-Elche, Murcia, Cartagena, and Castellón.

- Andalucia (8,100,000 inhabitants) which includes the cities of Andalucia and those of Ceuta, Melilla and Gibraltar, with Sevilla as the principal node, conforming to a polycentric system comprising Málaga, Granada, Córdoba, Cádiz-Jerez, and Almería, Huelva and Algeciras-Gibraltar.

- The Atlantic Islands (2, 600,000 inhabitants) a binational space/project formed by the autonomous archipelagos, with the Canary Islands and their metropolitan city islands of Santa Cruz de Tenerife and Las Palmas de Gran Canaria having a greater populational and economic importance than Funchal or Ponta Delgada.

The urban hierarchy of the system can be observed to be generally balanced, if the whole is taken into account, although on the level of the Portuguese system and certain Spanish regions, a higher level of primacy or monocentralism is notable, with an attendant imbalance in hierarchical urban levels, seen in indicators such as residential population, airport passengers, goods in ports, sale of newspapers, or university student population. Other indicators, such as the market share, could possibly specify with even greater precision, if it were possible, the 
Table 1. Urban Hierarchy of 25 Selected Capital Centres in Spain and Portugal Own Compilation of Municipal Statistics

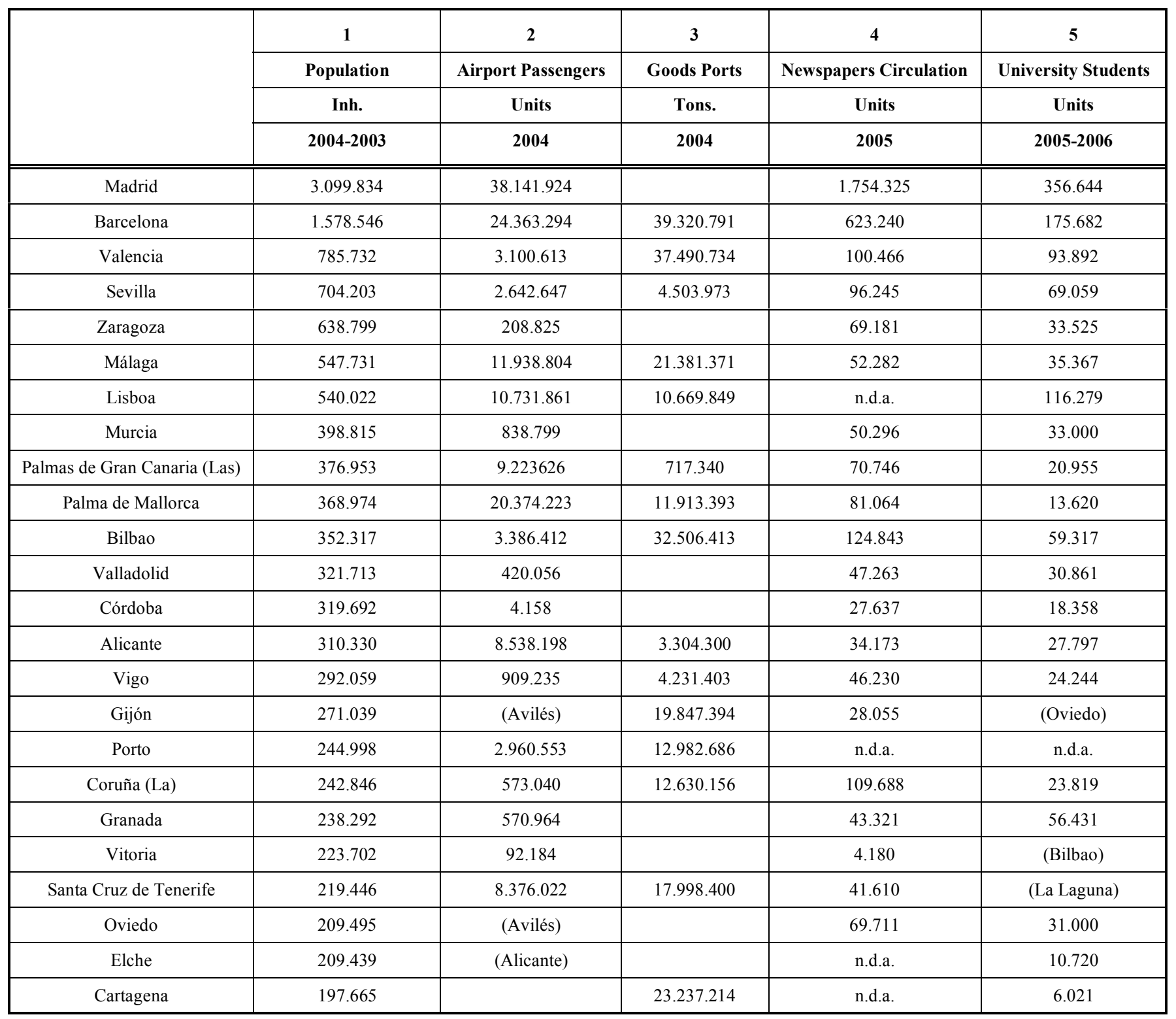

hierarchical order, but this data is not available in the case of Portugal.

According to these bases therefore, 24 agglomerations (Table 1) with more than two hundred thousand inhabitants can be identified, ordered by population size, of which only two are Portuguese, followed by another 88 with between two hundred thousand and fifty thousand inhabitants, of which 21 are Portuguese. That is to say, a total of 113 urban and metropolitan areas. Where values cross, the undisputed ascendancy of Madrid can be seen (ranking 1), as well as Barcelona (ranking 2), whilst Lisboa and Valencia are in third and fourth place respectively. Exceptionally, with some indicators other cities stand out, for their specialisation in port activities (Algeciras, Tarragona and Huelva) or airport activities (Faro and several island cities). On a second level, there are the regional metropolises with similar characteristics in terms of population size and central functionality, and with a consolidated model of conurbanisation, between whose centres it is difficult to establish a hierarchy; Bilbao, Porto, Sevilla, Zaragoza, central Asturias, Tenerife, Gran Canaria, Mallorca, MálagaCosta del Sol. On a third level, there are sub-regional metropolises and various medium sized cities which constitute about a hundred centres with more than 50,000 inhabitants. In its entirety, the system supports another two hundred centres, small cities with more than 10,000 inhabitants.

Various cities of different sizes and hierarchical position show action and co-operation strategies, sometimes united in supra-regional level projects, for example, Atlantic Arch [2] and at other times directed by interests determined by their functional specialisations, for example, a seaport specialisation, or by objectives aimed at achieving new infrastructures or competitive services with territorial scope. This has been the case for those recent strategies aimed at hosting international events (Barcelona, Sevilla, Lisboa, Valencia and Zaragoza) of a commercial, cultural or sporting nature, or in order to establish themselves as permanent 
headquarters for international organisations and businesses of the first order, as conference centres, or fair and festival locations.

Following in this line, certain Iberian metropolises occupy a privileged position through their possibility of offering more autonomy and leadership on an international scale, or at least on a supra-regional scale, as is the case with Madrid, firstly, and with Barcelona and Lisbon, followed by Valencia, Bilbao, Sevilla, Porto, Granada, Palma de Mallorca and Málaga, as the study [3] shows, where 15 indicators were applied to 180 European agglomerations, permitting the identification of the most attractive and competitive cities. Other metropolises and medium sized cities have developed a certain attraction, such as Alicante, Zaragoza, Pamplona, Cádiz, Tarragona, Córdoba, San Sebastián, Santander, Valladolid, Vigo, Vitoria, La Coruña, and Murcia. The rest of the cities not mentioned, including the Atlantic islands, are striving to place themselves in the hallowed circle of the more competitive cities, backed by their specialisation in ports or airports, culture and university education, commerce and tourism, or industrial or institutional centres.

\section{METHODOLOGY AND RESULTS}

\section{The Urbanisation Process and Trends: A Bibliographical Review}

The dynamics of Spanish and Portuguese cities have received ample attention from geographers and town planners, from amongst whose publications the works of certain authors, and joint works will be highlighted here. These are, amongst others, certain studies of metropolises analysed in a European, Iberian or national context [4-8] which have borne fruit as dossiers or diagnoses of the situation, presented in a large format with graphic illustrations. In general, they draw attention to the transition from a compact city model to a dispersed city and metropolitan model, and cover new ground, adopting different structures for growth; mononuclear, polynuclear or dual, such as the 'urban region' (Madrid), the 'metropolitan region' (Barcelona), the 'metropolitan county' (Bilbao, Zaragoza), the 'urban agglomeration' (Málaga, Granada), the 'central area' (Asturias), the 'functional area' (San Sebastián) or the 'metropolitan area' (Alicante-Elche).

The treatment of different sized cities, urban peripheries, and new spatial forms, or the processes of transformation and planning, has been the focus of the attention of the Spanish Association of Geographers (Asociación de Geógrafos Españoles) on various occasions [9, 10] or of monographs in certain specialist Spanish journals (Ciudad y Territorio, Ería, Estudios Geográficos, Ingeniería y Territorio, Urban) and Portuguese journals (Finisterra, Inforgeo).

A general synthesis of the urbanisation process can be consulted in various works [11-18], where the changes which have occurred over the last decades, parallel with a boom in the construction industry, such as is the case at present, and other, more restrained, periods for property developers, are described. A dynamic where a variety of situations arise, in a phase defined by the imperative of neoliberal capitalism, where "in order to adapt to the new conditions of competitiveness, strategies of urban promotion, marketing approaches and urbanisation of image are put into motion, funded by Community funds, the privatisation of urban services and city space, controlled by monopolies..." (property development groups). "This neo-conservatism coexists and contrasts with universal criteria for sustainable urban development and the search for quality..." [14, p. 267]. A result of all this will be a double standards system for new urban, periurban and suburban development sites, where some are in accordance with the regulations, wellplanned and of high quality, whilst others will produce spontaneous and illegal residential and industrial landscapes on the periphery. Thus the challenge for Spain and Portugal is how to control their cities and metropolises, which discuss $[12,16]$. In this respect, significant advances have recently been made through the creation of the status of metropolitan areas for Lisboa and Porto, and the Spanish Law of "means for modernising local government", 2003, applied to medium sized and large cities, together with the new standards put forward in the Carta Municipal (Municipal Charter) and the Ley de Capitalidad de Madrid (Law of Capital Status of Madrid), 2006.

At the same time, with respect to a more individual treatment, both property development and urban housing have been the subject of certain publication [19] which have drawn attention to the housing construction movement in Spain since the formal development of the city, and in particular, to the characteristics of the principal property developers, that is, an analysis of the development and the developers. Another example is the study of the processes of industrial production restructuring since the 1980s which has affected Spanish metropolises, especially around railway and port zones, which have become the new planned peripheral areas as well as being consolidated as truly factory "axes" more and more distant and joined by the transport network with the consequent waste of land which the, often indiscriminate, 'scattering' of warehouses implies, together with the negative environmental impact they cause [20].

In the same way, studies of certain individual cities and metropolises continue to be, to a greater extent, the most frequent, representing the fruits of doctoral, individual and collective research, where urban evolution is examined together with trends in growth, the resultant problems and impact caused, and the formation of urban and metropolitan areas. Such is the case, in the first instance, of the research carried out [21] on growth which is both centred on specific geographical points and dispersed, and the consolidation of Valladolid as an agglomeration, or that [22] on the polycentric and fragmented metropolitan conformation of Lisboa. On present also certain ideological and conceptual reflections [23, 24] on the space/project "Catalonia-city", seen as the inevitable future for the urban Catalan region, where the territory will be joined by an urbanised network revolving around Barcelona as the head, based on the undisputed sense of Catalan national identity, for which territory is a driving force. In fact, of the 6,300,000 inhabitants of Catalonia, almost half are concentrated around the metropolitan area (three million), and still more in the metropolitan region, which has been continuously expanding over the past ten years (with 4,700,000 inhabitants, or $77 \%$ of the total population of Catalonia). 
In the second instance, it is worth commenting on the results of certain recent studies of particular cities and their surrounding areas; the first, chronologically, was carried out [25] on Gerona and its urban area (one of the cities with the highest standard of living in Spain), looking at the economic transformation that this medium sized city underwent in the last quarter of the twentieth century. In the course of this transformation, its periurban space was consolidated with other neighbouring municipalities due to worker mobility and the job market. The study also looks at certain worrying aspects of the present situation with regard to the compartmentalisation of land use and urban fragmentation, and the determining role that transport networks (such as the high speed railway) will have, in the end, on the definition of the urban area.

Somoza's thesis [26] on Orense depicts the successive construction-reconstruction of this medium sized Galician city, which in recent years has expanded in a scattered way: "The city is exploding, and its fragments are expanding over a radius of several kilometres...forming a de facto urban dispersion over what was previously considered to be rural territory", where the periphery, lacking now its traditional agricultural activity, is offering land for whatever urban activity arises, with the result that a jumble of uses and infrastructures which disarticulate the landscape has become widespread.

In another doctoral thesis [27] on Burgos, a medium sized, compact city, it is observed that the city "still had, at the end of the twentieth century, unfinished business; that of regulating and integrating the different, and increasingly diverse, elements which make up its spatial structure". At the same time, the city is immersed in a wide range of cultural urban projects and the construction of infrastructures such as the new high speed railway station and line, the airport, the Integrated Transport Centre, as well as increasing land available for industrial purposes in the quest for a balance between industrial and tertiary activities. Meanwhile, questions arising from the permanent challenge of planning and controlling construction in the city, balancing the reality of the city and planning ideals of a rational urban space, remain unanswered.

Finally, the evolution of the city of Barcelona is the subject of a study [28]. The last two chapters look at the urban rehabilitation and restructuring of the city from 1980 onwards, as a result of the 1992 Olympic Games being held there. All 'special projects' to the present day, originated in that moment, and attempt to tackle problematic areas of the urban and suburban structure, such as the waterfront, the Olympic town, the ring roads, forum and seafront diagonal, and new centres in the first case, and the port and airport expansions, the Delta del Llobregat plan, and the arrival of the high speed train in the second case. This has led to the creation, over the past few years, of a new image of urban planning successes, based on private and public sector cooperation in the realisation of these projects, elevating Barcelona to the level of a European-wide model of a compact and dynamic city with a future. Likewise, Capel $[29,30]$ produced a penetrating critical examination of the so-called 'Barcelona model', calling into question the lack of dialogue with, and participation of, the city's inhabitants in the city projects, and drawing attention to both the City
Council's apparent obsession with modernity and large scale urban planning interventions based on external image and marketing, and the 'ivory tower' approach of local politicians, convinced of the correctness of their vision.

\section{PRESENT DAY DYNAMICS OF METROPOLITAN AREAS AND MEDIUM SIZED CITIES: A FIELD STUDY}

During the period 2004 to 2006 , the author was able to visit and study in depth most of the medium sized cities, and all of the metropolitan areas, in the Iberian Peninsula, with the aim of gathering urban and territorial planning information, both from documentation and through interviews with those responsible at local and regional level (examples: university professors experts in Lisboa, Porto and Valencia; Urban Planning Office and Ebrópolis Foundation in Zaragoza; Offices of Urbanism of Alicante and Elche, councilmen of urbanism of Gijón and Avilés, municipal offices of planning of Granada and Bilbao, Managers of urbanism of Sevilla and Málaga, Urban Planning Office of Murcia, General Assistant directors of Territorial Planning of the Autonomous Communities of Madrid and Catalonia, etc). During the interviews, they were asked various questions about a) the boundary municipality of urban areas and metropolitan areas, b) the territorial and urban model, c) the Administration's decision-making process and governance, d) new infrastructure projects, e) the urban competitiveness. On the basis of this, there follows an examination of a synthesis of the state of metropolitan dynamics in thirteen agglomerations and metropolitan systems, beginning with the biggest Portuguese cities.

Lisboa, outstanding centre of the Atlantic seafront and a polycentric metropolitan area, displays a lack of facilities and infrastructures in the peripheral suburbs, and preserves different planning standards for the central metropolis, the metropolitan periphery, and the regions of Lisboa and the Vale do Tejo. In recent years, influence has been exercised by certain events, and exceptional projects have been carried out, such as the Oriente sector and the second Bridge (Expo '98). Strategies have been designed based on the aim of "recentralising the metropolitan area, whilst making the region polycentric". In this respect, Oeiras and Cascais, in the west of the city, have been considered to be the most attractive structural spaces in the city, whilst the interstices and the Banda Sur (area south) of the river - critical urban areas in old Lisboa - are considered problematic spaces. Emergent spaces are defined as the Ribeirinha, as well as protected natural spaces, and regional projects are represented by the new airport and the arrival of the high speed train.

Porto, Portugal's second biggest city and the northern metropolis, is well positioned in relation to the Galician cities on the Atlantic axis, with which it co-operates in terms of strategies. Nevertheless, a fragmented approach to local territorial administration dominates, which pays no heed to urban dynamics, giving credence to the saying "Porto is a small thing surrounded by a huge mass of dispersed and unplanned housing". Large scale projects include the development of an underground metro system, expansion of the airport, and the arrival of the high speed train, as well as 
revitalising the old centre and promotion of cultural facilities such as the Multi-Media Centre.

Madrid, urban agglomeration, metropolitan area and urban region, practically a reflection of regionalisation policies, still lacks a Regional Territorial Strategies Plan to direct its expansion and development, and control of these aspects has only been achieved in certain centres of development. Meanwhile, the dormitory towns have begun to develop both an identity and new tertiary centres. Examples of large scale projects recently concluded, in process or projected include the expansion of the airport, the channelling underground of the M-30 motorway, new centres in Castellana Norte-Chamartín and Campamento, new metro lines on the North and East lines, and improvements to railway access.

Barcelona, the great Mediterranean city, recently introduced territorial planning standards, in the quest for a coherent position on local and county urban planning in the context of a 'metropolitan region' of some $3,000 \mathrm{~km}^{2}$. Large scale projects include macro-infrastructures such as the Termini for the high speed train (the 'AVE'), expansion of the airport and seaport, the Llobregat River Delta project, as well as facilities such as the judicial district and on-going neighbourhood rehabilitation projects.

Zaragoza, an agglomeration which is an important logistics centre and the metropolis of the Ebro river valley, maintains an intense flow of regional exchange, above all with Catalonia. On the other hand, it suffers from a lack of management and co-ordination above municipal level, as well as a lack of integration policies. Decision-making structures are yet to be defined, and there is lively confrontation between local and regional administrations, each carrying out their own particular project in the case of Expo 2008 on the one hand, and the Plataforma Logística (Logistics Consortium) on the other. Developments over recent years have revealed a certain dependence on external initiatives such as the Ebro motorway, the AVE (high speed train), the military air base, or the Opel factory, in contrast to autonomous region projects, focussed on logistics and large scale projects concerning residential and industrial land use.

On a functional level, the metropolitan area of AlicanteElche is compartmentalised, with each city turning its back on the other (an airport at Elche, and a port in Alicante) whilst maintaining interrelationships with other centres of population falling within their sphere of influence. In Alicante, new projects include the new AVE station, the second stage of the motorway, or the implementation of a tramway system, whilst in Elche, efforts are directed towards the eastern ring road, a new high speed connection with Alicante, and a railway connection with the airport.

Central Asturias is something of a conurbation in search of an identity, dependent on regional government action. In the absence of a Territorial Plan, policies are patchy and sector based. Thus the biggest city, Gijón, has been through a profound industrial-naval crisis, from which it has only recently resurfaced due to an innovative tertiary sector which has brought about a balance between industrial and service functions. Large scale infrastructural projects include the expansion of the bulk handling port, the AVE and the 'metro train', as well as the 'Laboral' complex. Meanwhile, Oviedo, the region's administrative capital, is also a tertiary centre with projects involving the AVE and the 'metro train', in addition to a northern ring road, a new general hospital and a conference centre. Avilés is concentrating its efforts on the reclassification of land around the estuary for industrial and residential purposes, as well as the integration of the railway and Arts Centre. The coalfield cities of Mieres and Langreo are of note for their projects funded by plans for the regeneration of mining areas, which include land for industrial purposes, a new hospital, museums, and the integration of obsolete spaces.

Granada, an agglomeration with a fast growing peripheral area, now has a Territorial Plan for its urban area and ambitious projects for a second ring road system, an underground metro system, a macro industrial estate, a health campus, cultural, leisure and commercial centres, as well as metropolitan parks, expansion of the airport, and an Intermodal Transport Centre. Present residential trends are for a move back to the city centre from the peripheral residential areas, as a result of the rehabilitation of old quarters and neighbourhoods.

Sevilla, now a consolidated metropolitan area with a Territorial Land Use Plan, nevertheless has suffered until now from notably uncoordinated policies, where a metropolitan model arises whenever it is necessary to bring costly services up to date, but not when there is an attempt to implement a territorial model. The suburbanisation process has been underway since 1992, and has now reached the second ring road. The model for this growth can be identified as that of disparate urbanisation, displaying a lack of public transport and communications infrastructures, in addition to the generation of dormitory towns which lack facilities, and the appearance of new centres (industrial estates, leisure and commercial centres). New projects are focused on completing the railway circuit, the suburban underground metro, the 40 ring road, the metropolitan South Park, expanding the port, the second phase of the fluvial front, or the revitalisation of the capital's centre.

Málaga is situated on a stretch of coastal territory organised around the capital city. Since the 1980 s, this city has witnessed a decentralisation of services along with a trend towards an explosion in the growth of residential areas. Current projects include the AVE and an Intermodal Transport Centre, an underground metro system, a second ring road system, reorganisation of the port and its integration into the city, and new cultural centres.

Murcia is a self-made city based on neighbouring municipalities and invading the surrounding 'Garden' territories (the province of Murcia is known as the market garden of Spain - translator's note). In principle a rural area, urbanisation has gone ahead with virtually no controls imposed. The model of the city at the end of the last century has been overwhelmed by the rapid growth of the periphery, but without a solid base for the said growth. Major projects include a new regional airport, new points of access for the motorway, the AVE, cultural centres and a new General Hospital.

The continuous growth of the metropolis of Valencia has caused the disappearance of the Mediterranean 'market garden', swallowed up by the urbanisation of land made 
possible by the extension of the underground metro system and new motorways. Local municipalities are under pressure from land owners to release more building land, with the result that each municipality acts individually, given that there is no Territorial Plan and that the Metropolitan Consortium only offers partial services. New projects include a central park, an underground metro connection with the airport, the final opening of the seafront promenade, expansion of the port (where the American's Cup will be held this year) and airport, the AVE, and a new ring road.

Finally, Bilbao carried out an internal reconstruction some years ago which included the restructuring of the neighbourhood around the estuary, and an exceptional turnabout in image based on the opening of the Guggenheim Museum, as well as the move of the Trade Fair to Baracaldo, expansion of the port and airport, and new housing developments, all the result of a coherent territorial and land use planning strategy.

\section{CONCLUSION}

In synthesis, it should be added that Iberian urban areas and medium sized cities can be grouped according to the following typologies: certain individual cities (Vitoria would be an example here) exercise efficient control, so that growth is compact and development sustainable, together with territorial measures for their surroundings; other cities (for example, Pamplona) achieve compact and well planned growth within the city itself, but not in the neighbouring municipalities, with the result that the surrounding area is unbalanced. However, the majority of cities (examples are León and Coimbra) permit uncontrolled development of the city and its surrounding area, leaving some pericentral spaces empty whilst expansion is scattered and new periurban developments are dispersed. These three typologies can be seen in various forms in all Spanish and Portuguese cities, almost always with a similar dynamic of marked spatial expansion and the predominance towards a model of dispersed urbanisation. As was stated at the beginning, Iberian cities are faced with the challenges to local, and above all, supralocal government, in order to overcome the problems deriving from such a rapid pace of urban expansion.

\section{REFERENCES}

[1] Laborde P. Les villes espagnoles. Bordeaux: Presses Universitaires de Bordeaux 2005.

[2] Laborde P. Dir. L'Ibérie atlantique. Paris: Éditions de l'AubeIAAT 1996

[3] Rozenblat C, Cicille P. Les villes européennes. Analyse comparative. Paris: La Documentation Française 2003.

[4] Borja J, Muxi Z, Eds. Urbanismo en el siglo XXI: Bilbao, Madrid, Valencia, Barcelona. Barcelona: Édicions UPC 2004.
[5] Domingues A. Cidade e Democracia: 30 anos de expansão urbana em Portugal. Lisboa: Argumentum 2006.

[6] Ferrao J (Coord). As regiões metropolitanas portuguesas no contexto ibérico. Lisboa: DGOTDU 2002.

[7] Font A. Ed. L'explosió de la ciutat. Barcelona: COAC 2004.

[8] Portas N, Domingues A, Cabral J. Políticas urbanas. Tendências, estratégias e oportunidades. Lisboa: Fundação Calouste Gulbenkian 2003.

[9] Domingues RR (Coord). La ciudad. Tamaño y crecimiento. Málaga: Universidad de Málaga-AGE 1999.

[10] Lopez TL, Relea Fernandez CE, Somoza MJ (Coords). La ciudad. Nuevos procesos, nuevas respuestas. León: Universidad de León 2003.

[11] Gaspar J, Simoes JM. Planeamento e Ordenamento do Território. In: Medeiros, CA (Dir). Geografia de Portugal, vol. IV. Lisboa: Circulo de Leitores 2006.

[12] Nel.Lo O. Las áreas metropolitanas. In: Gil Olcina A, Gómez Mendoza J (Coords). Geografía de España. Barcelona: Ariel 2001; pp. $275-98$

[13] Lopez TL. The contemporary evolution and new dynamics of cities in Spain and Portugal. In: Lois RC, Somoza J, Eds. Urban changes in different scales: systems and structures. León: Universidad de León, 2006; pp. 187-96.

[14] Quiros LF, Tome FS. El proceso de urbanización: las ciudades. In: Gil Olcina A, Gómez Mendoza J (Coords). Geografía de España. Barcelona: Ariel 2001; pp. 251-74.

[15] Sa MT. (Coord). Sistema Urbano Nacional. Cidades Médias e dinâmicas territoriais. Lisboa: DGOTDU 1997.

[16] Sa MT Portugal na transição do século. Retratos e dinâmicas territoriais. Porto: Afrontamento 2004.

[17] Varios Autores. Géographie d'une Espagne em mutation. Prospections Aériennes II. Madrid: Publications de la Casa de Velázquez 1990.

[18] Varios Autores. Atlas estadístico de las áreas urbanas en España 2004. Madrid: Ministerio de la Vivienda 2005.

[19] Vilagrasa J, Ed. Vivienda y promoción inmobiliaria en España. Lleida: Universitat de Lleida 1997.

[20] Mendez Gutierrez del VR, Caravaca BI. Procesos de reestructuración industrial en las aglomeraciones metropolitanas españolas. Madrid: MOPT 1993.

[21] Garcia FJ. Valladolid. De la ciudad a la aglomeración. Barcelona: Ariel 2000.

[22] Barata ST. Lisboa, periferia e centralidades. Oeiras: Celta Editora 2001.

[23] Nel.Lo O. Cataluña, ciudad de ciudades. Lleida: Editorial Milenio 2002.

[24] Ribas i Piera M. Barcelona i la Catalunya-ciutat. Barcelona: Angle Editorial 2004

[25] Oliver AJ. De la gran Gerona a l'àrea urbana de Girona. Girona: Ayuntament de Girona-Caixa Catalunya 2000.

[26] Somoza M J. Ourense. La ciudad en el tiempo y el espacio. León: Universidad de León 2002.

[27] Andres LG. La estructura urbana de Burgos en los siglos XIX y XX. Burgos: Caja Círculo 2004; Vol. 2.

[28] Busquets J. Barcelona, La construcción urbanística de una ciudad compacta. Barcelona: Ediciones del Serbal 2004.

[29] Capel H. El modelo Barcelona: un examen crítico. Barcelona: Ediciones del Serbal 2005.

[30] Capel H. El debate sobre la construcción de la ciudad y el llamado modelo Barcelona [Scripta Nova, Barcelona, Universidad de Barcelona, 15 febrero 2007, 233]. En línea: http://www.ub.es/geocrit/sn/sn-233.htm 